\title{
Ulusal Hava Kalitesi Gözlemleri Bağlamında Türkiye'de Hava Kirliliğinin Yerel Durum ve Eğilim Görünümlerinin Belirlenmesi
}

\begin{abstract}
Abdulvahap Çağatay DİKMEN ${ }^{1}$
ÖZ: Hava kalitesi, insan sağllğl ve etkinliğini etkileyen en önemli etmenlerden birisidir. Havanın kalitesini belirlemede dikkate alınan hava kirletici değişkenlerine yönelik olarak Türkiye'de düzenli gözlemler gerçekleştirilip toplanan veriler ilgili veri tabanlarında saklanmakta ve paylaşılmaktadır. Hava kalitesinin anlık değerlendirmesinin yanı sıra, uzun dönem istatistiksel görünümlerinin ve eğilim varlı̆̆ının ortaya koyulmasl, kalite ile ilgili yaşanan problemlerin çözümünde önemli rol oynamaktadır. Bu çalı̧̧mada, hava kalitesi gözlem istasyonlarından derlenen değiş̧kenler istasyonlar özelinde istatistiksel yaklaşımlarla incelenmiş, dönemsel eğilim analizleri gerçekleştirilerek dönemler kapsamı ve arası görünümler ortaya koyularak detaylı çalışma gerektiren sıcak noktaların ortaya çıkarılması hedeflenmiştir. Bulgular inceleme dönemleri kapsamında değerlendirildiğinde, PM10 açısından bazı illerdeki nisbi artışlara ră̆men Türkiye genelinde dönem ortalama değerlerinde genelde azalma, SO2 açısından ise Orta ve Doğu Karadeniz ile Akdeniz'in doğusu ve Ege civarı dönem artıslarına rağmen genel itibarla azalma yönünde değişimler olduğu belirlenmişstir. Ĕğilim analizleri sonucunda ise eğilim görünümlerinin istasyonlar bazında farklllaştı̆̆ belirlenerek özellikle olumsuz görünüme sahip konumlarda daha detayl inceleme gereği ortaya koyulmuştur.
\end{abstract}

Anahtar Kelimeler: Hava Kalitesi, Zaman Serisi, Parametrik Olmayan Eğilim Analizi JEL Kodu: Q53, C22, Q58

\section{Determination of Local Status and Trend Views of Air Pollution in Turkey in the Context of National Air Quality Monitoring}

\begin{abstract}
Air quality is one of the most important factors affecting human health and effectiveness. In determining the air quality through air pollutant variables considered, regular observations are performed and the data are stored in databases and disseminated in Turkey. In addition to any immediate evaluation of air quality, unfolding long-term statistical views and trends play an important role in the solution of quality problems. In this study, variables compiled from the air quality monitoring stations were examined by statistical approaches within the individual contexts of observation stations, seasonal trend analysis were performed and it was aimed to reveal hot spots that require further attention. When the findings are examined with respect to the investigated periods, general decreases in the average values of PM10 at the scale of Turkey, against relative increases in some provinces, and again decreases in $\mathrm{SO} 2$ in a wider scale, excluding the central and eastern parts of the Black Sea region, east Mediterranean and some parts in Aegean, were basically identified. As a result of the trend analysis, the trend views appeared to differ at the stations level and the need for more detailed analysis was revealed especially in the areas with negative outlook.
\end{abstract}

Keywords: Air Quality, Time Series, Non-parametric Trend Analysis JEL Codes: Q53, C22, Q58

Geliş Tarihi / Received: 23/02/2019

Kabul Tarihi / Accepted: 11/03/2019

\footnotetext{
${ }^{1}$ T.C. Çevre ve Şehircilik Bakanlığı, Çevresel Etki Değerlendirmesi İzin ve Denetim Gn. Md., Ankara, cagatay.dikmen@csb.gov.tr, orcid.org/0000-0003-4448-2649
} 


\section{Giriș}

İnsan yaşamının, diğer doğal kaynaklarla birlikte ihtiyaç duyduğu en önemli kaynaklardan birisi de soluduğumuz hava olup sağlıklı birey ve toplum yaşamları için bizi çevreleyen havanın kalite bakımından yeterli nitelikte olması büyük önem taşımaktadır. Bu bilinçten hareketle, ülkemizde ilgili kurum ve kuruluşlar aracılığı ile soluduğumuz havanın kalitesinin korunması ve iyileştirilmesi için etkin bir izleme ve değerlendirme müktesebatı geliştirilmiş olup, 06.06.2008 tarih ve 26898 sayılı Hava Kalitesi Değerlendirme ve Yönetimi Yönetmeliği, tüm üst kanunlar ve ilgili yönetmelikleri destekleyici yönde bu alanda öne çıkan politika araçlarından birisi olarak öne çıkmaktadır (Resmi Gazete, 2008).

Hava kalitesinde yaşanan bozulma ve dalgalanmaların en önemli etkisi canlı yaşamı üzerinde olmaktadır. Hava kalitesini tehdit eden önemli kirleticilerden, örneğin, kükürtdioksit $\left(\mathrm{SO}_{2}\right)$ çeşitli solunum yolu rahatsızlıklarına neden olmakta, partikül madde (PM) özellikle kanser, kalp problemleri, solunum yolu hastalıkları üzerinde etkili olmakla birlikte bebek ölüm oranlarında artışa yol açabilmekte, karbon monoksit (CO) kanın oksijen taşıma kapasitesinde azalmaya neden olarak ölümle sonuçlanabilen olumsuz etkilere sahip olabilmektedir (ÇŞB, 2019a). Doğrudan sağlık etkilenmelerinin yanı sıra, hava kirliliğinin yol açtığı sağlık problemleri nedeniyle tedavi giderleri ve hava kalitesinin bozulduğu dönemlerde aşırı ilaç kullanımları üzerinden sebebiyet verdiği ekonomik zararlar da kayda değer olmaktadır. Tüm bu olumsuz neticeler dolayısıyla çeşitli hava kirleticilere yönelik olarak düzenli gözlemlerin gerçekleştirilmesi ülkemizde en büyük önem verilen konulardan birisi olmuş ve gözlem ağı tasarımı, ișletilmesi ve kamunun güncel bilgilendirilmesi bağlamında önemli uygulama örneklerinden birisi olan Ulusal Hava Kalitesi İzleme Ağı, T.C. Çevre ve Şehircilik Bakanlığı koordinasyonunda işletmeye alınmıştır (ÇŞB, 2019b,c). Bu kapsamda derlenen veriler, ilgili kurumlar ve akademik uzmanlarla paylaşılarak, yerel ve/veya bölgesel ölçekte bilimsel araştırma çalışmaları gerçekleştirilmiştir. Akyürek vd. (2013), Kocaeli örneğinde kirletici parametre konsantrasyonlarının zamana bağlı değişimlerini ve yönsel eğilim varlığını incelemiş ve bulguları mekansal gösterimli olarak ortaya koymuştur. Mayda ve Yılmaz (2013) ile İskender vd. (2016), Düzce ili özelinde SO2 ve PM10 değişkenleri üzerinden hava kalitesini ilgili meterolojik değişkenlerle birlikte incelemiş ve izleme ve denetim mekanizmasının önemini ortaya koymuşlardır. Oğuz ve Pekin (2015) meteorolojik koşulların hava kirliliği üzerine etkilerinin incelenmesi için Keçiören ilçesi örneğinde çalışmalar gerçekleştirmiştir. Şişman (2019), Türkiye'de işletmedeki termik santraller civarından seçilen ulusal hava kalitesi izleme istasyonlarında kirletici verilerinin dönemsel değişimlerini trend analizleriyle incelemiş ve hava kalitesinde iyileştirme yönündeki çalışmaların sürekliliğinin gereğine işaret etmiştir.

Meterolojik hava koşullarındaki değişimlere benzer şekilde dinamik bir yapıya sahip olan hava kalitesi önemli mekansal ve dönemsel değişimlere sahip olabilmektedir. Bu noktada, hava kalitesinin sürekli izlenmesi gereği bir kez daha 
ortaya çıkmaktadır. Kalitedeki olumsuz görünümlere ilişkin eğilimlerin incelenmesi veya hava kalitesi korunumu ve iyileşmelerinde sağlanan başarıların sürdürülebilir bir yaklaşımla sürekli güncellenerek değerlendirilmesi büyük önem taşımaktadır. Sunulan bu çalışmada, Ulusal Hava Kalitesi İzleme Ağına ait gözlem istasyonlarında derlenen verilerin günümüzden geriye gidilerek 2014-2018 yakın dönem ve 2009-2013 önceki referans dönem pencereleri içerisinde mekansal dağılımlı olarak istatistiksel açıdan analiz edilmesi ve hem dönemler içi hem de dönemler arası değişimlerin ortaya koyulması, istatistiksel açıdan nisbeten uzun dönem analizleri üzerinden araştırmacı ve karar vericilere hava kalitesinin durum ve değişimlerine yönelik bilgilerin sağlanması amaçlanmıştır.

\section{Materyal ve Yöntem}

Çalışmada Türkiye genelinde Ulusal Hava Kalitesi İzleme Ağı kapsamındaki 238 hava kalitesi gözlem istasyonundan (Şekil 1) derlenen $\mathrm{PM} 10, \mathrm{SO}_{2}, \mathrm{NO}, \mathrm{NO}_{2}, \mathrm{NO}_{\mathrm{x}}$, $\mathrm{O}_{3}$ ve $\mathrm{CO}$ kirletici değişkenleri incelenerek, değerlendirmeye esas 2009-2013 ve 2014-2018 dönemleri için nisbeten yüksek veri uzunluğuna (adedine) ve sürekliliğine sahip veriler içermesi bakımından PM10 ve SO2 değişkenlerinden yararlanılmıştır. Her iki değişken için de ilgili dönem istasyon gözlem verileri ayrıca incelenerek, beşer yıllık dönem uzunluklarına göre asgari 1250 adet gözlem verisi uzunluğuna sahip istasyonlar için istatistiksel analiz çalışmaları gerçekleştirilmiştir.

Şekil 1: Ulusal Hava Kalitesi İzleme Ağı kapsamındaki izleme istasyonlarının konumları ve güncel kalite indeksi görünümü

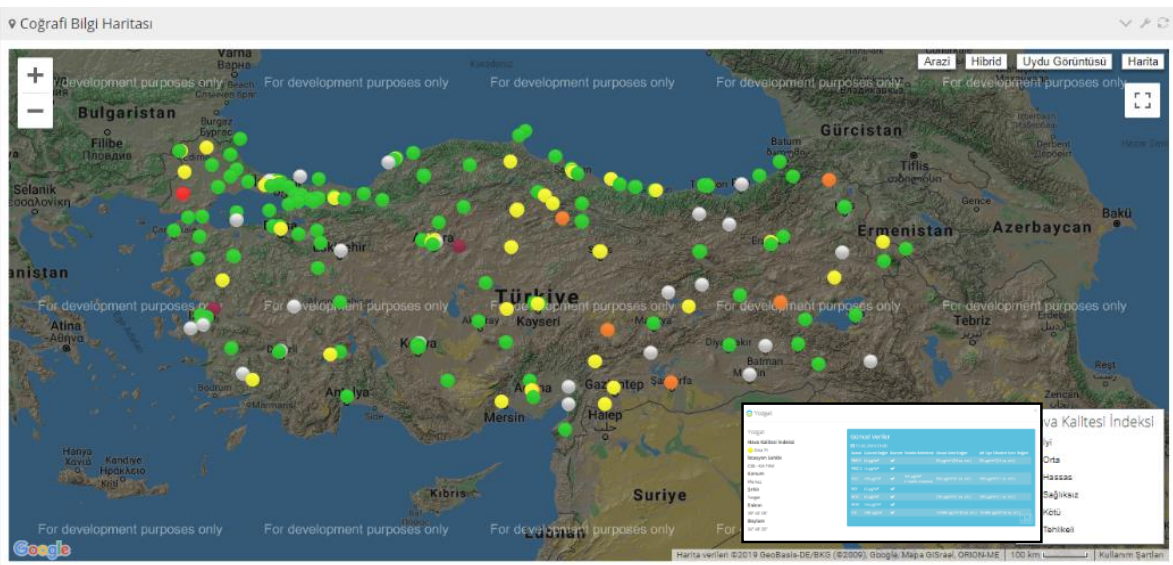

Kaynak: (ÇŞB, 2019b)

İstasyon veri setleri üzerinde temel tanımlayıcı örnek istatistiklerinin belirlenmesi aşamasının dışında, istatistiksel açıdan anlamlı eğilim varlığının ve derecesinin belirlenmesi işlemleri için ise açık kaynak kodlu $\mathrm{R}$ gelişim platformuna ilişkin RStudio entegre araç seti yazılımından yararlanılmıştır. Değerlendirmeye esas gözlem istasyonlarındaki kirletici değişkenlerine ait eğilim analizlerinin gerçekleştirilebilmesi amacıyla, RStudio ortamında Theil-Sen eğiliminin 
belirlenmesi için çalıştırılabilen TheilSen fonksiyonu kullanılmıştır (Şekil 2). Çalışmada parametrik bir eğilim testi (doğrusal eğilim veya t-testi gibi) yerine, veri seti toplumunun istatistiksel dağılımından bağımsız olması ve daha sofistike bir eğilim varlığı görünümü sunması bakımından Theil-Sen eğilim analizi (Theil, 1950) tercih edilmiştir.

Şekil 2: RStudio yazılımı arayüzü ve Theil-Sen eğilim varlığı analizi örnek gösterimi

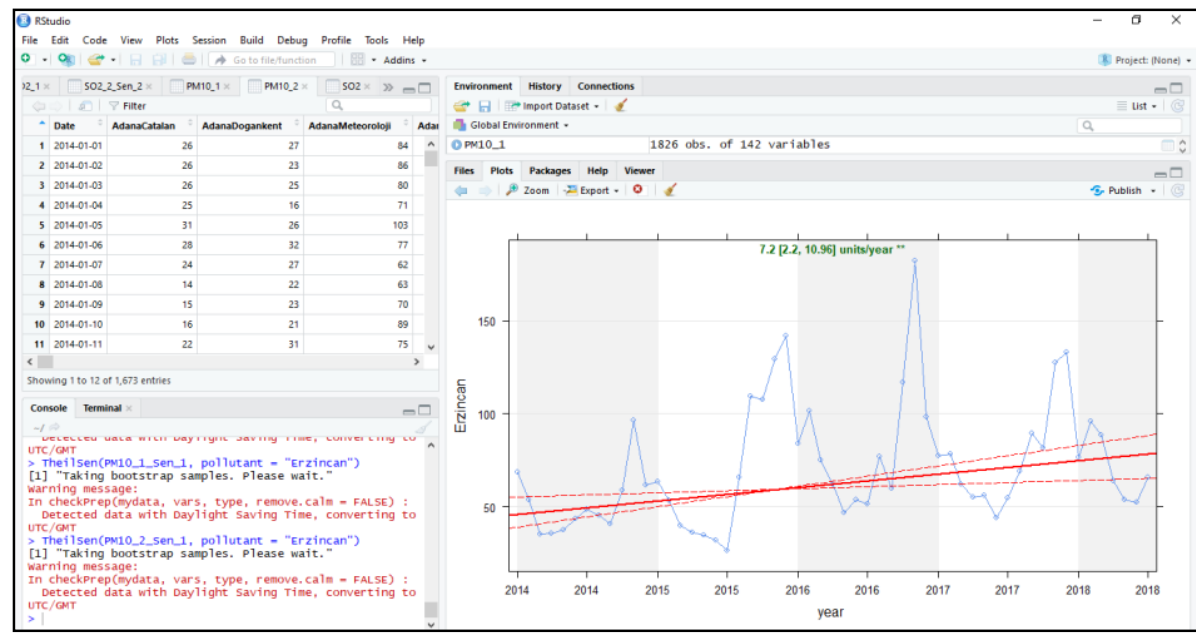

\section{Uygulama, Değerlendirme ve Sonuçlar}

Çalışma kapsamında incelenen istasyonlara ait PM10 ve $\mathrm{SO}_{2}$ veri setleri incelendiğinde, bazı istasyonlarda incelenecek değişkenler açısından değerlendirilen 2009-2018 döneminde gözlem bulunmadığı, bazı istasyonlarda veri uzunluğunun oldukça düşük veya tarafsız istatistik analizler açısından sıkıntı oluşturabilecek derecede yetersiz olduğu belirle nerek, asgari 1250 veriye sahip veri uzunlukları bakımından ilk inceleme dönemi olan 2009-2013 döneminde PM10 analizleri için 111, $\mathrm{SO}_{2}$ için 110 adet istasyon, bunu takiben 2014-2018 döneminde ise PM10 için 138, $\mathrm{SO}_{2}$ için ise 140 istasyon ayırt edilerek çalışmada kullanılmıştır.

İlk aşamada her iki kirletici için de 2009-2013 ve 2014-2018 dönem ortalamaları belirlenmiş ve istasyon konumları ile ilişkilendirilerek dönemsel ortalamaların mekansal dağılımları elde edilmiştir (Şekil 3a, b, 4a, b). Ortalama kirletici miktarlarının dönemler arası karşılaştırılması ise ikinci dönem değerlerinin ilk dönem değerlerine göre yüzdesel artış oranları hesaplanarak gerçekleştirilmiştir (Şekil 3c,d). Karşılaştırmalı sonuçlar incelendiğinde, PM10 değişkeni için en büyük dönem artışının $20.54 \mu \mathrm{g} / \mathrm{m}^{3}$ ortalama değerinden $46.66 \mu \mathrm{g} / \mathrm{m}^{3}$ değerine yükselme ile Giresun istasyonuna ait olduğu, Samsun İlkadım Hastane istasyonundaki \% 63.6 civarı artışın kayda değer olduğu ve bu istasyonları \% 20 üzerinde artış oranları ile Yalova, Erzincan, Muş, Sinop ve Muğla Yatağan sıralamasının izlediği belirlenmiştir. 
Şekil 3: (a) 2009-2013 ve (b) 2014-2018 dönemleri PM10 değişken ortalamaları ve (c) dönemler arası PM10 ortalama değer değişimleri

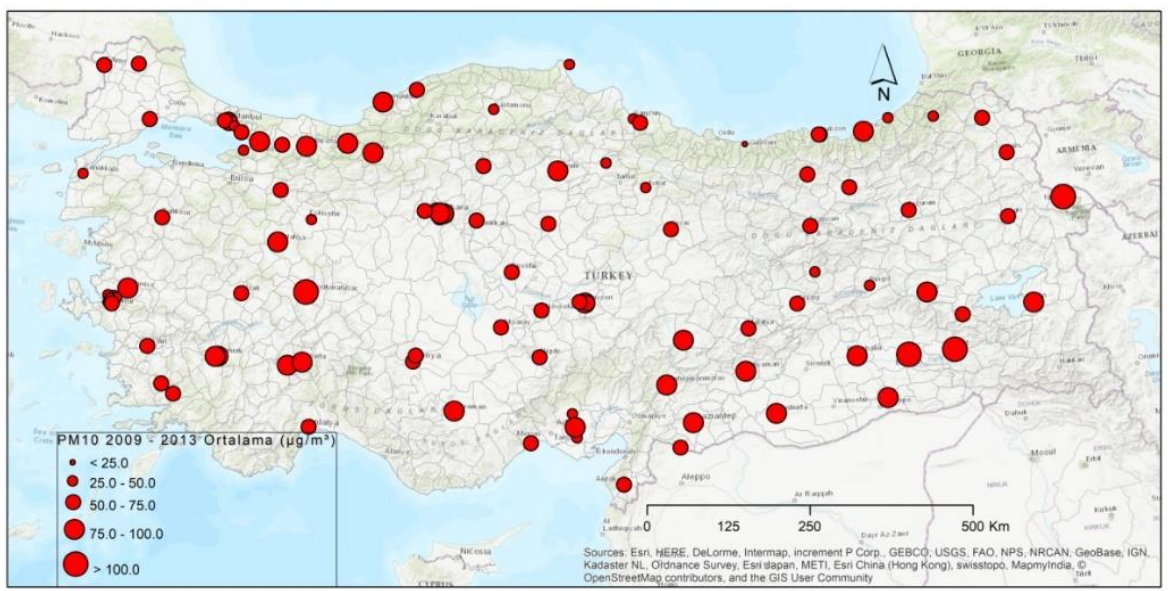

(a)

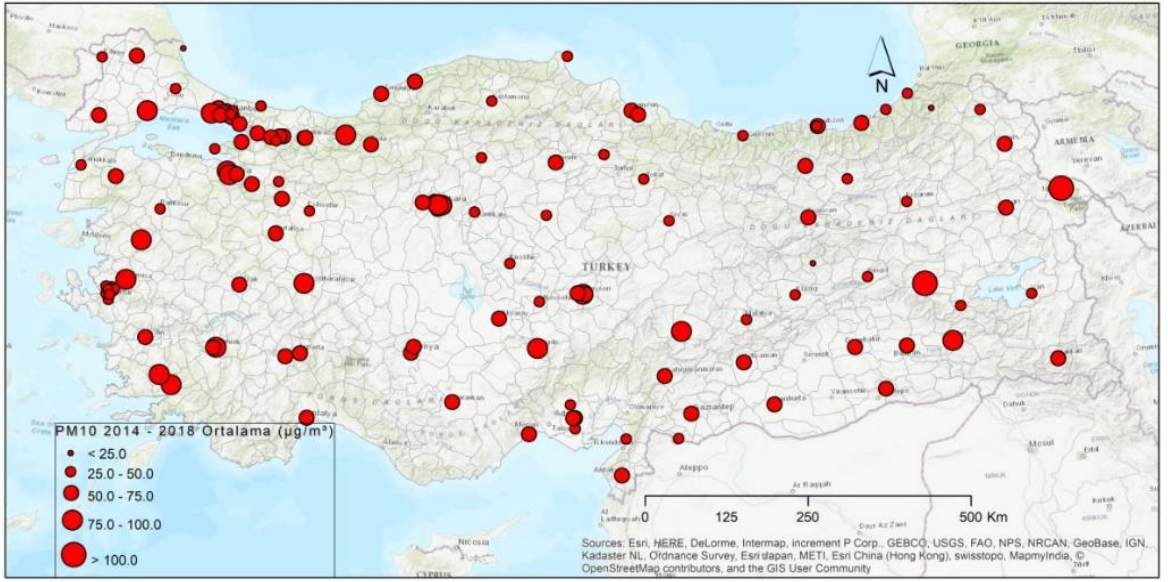

(b)

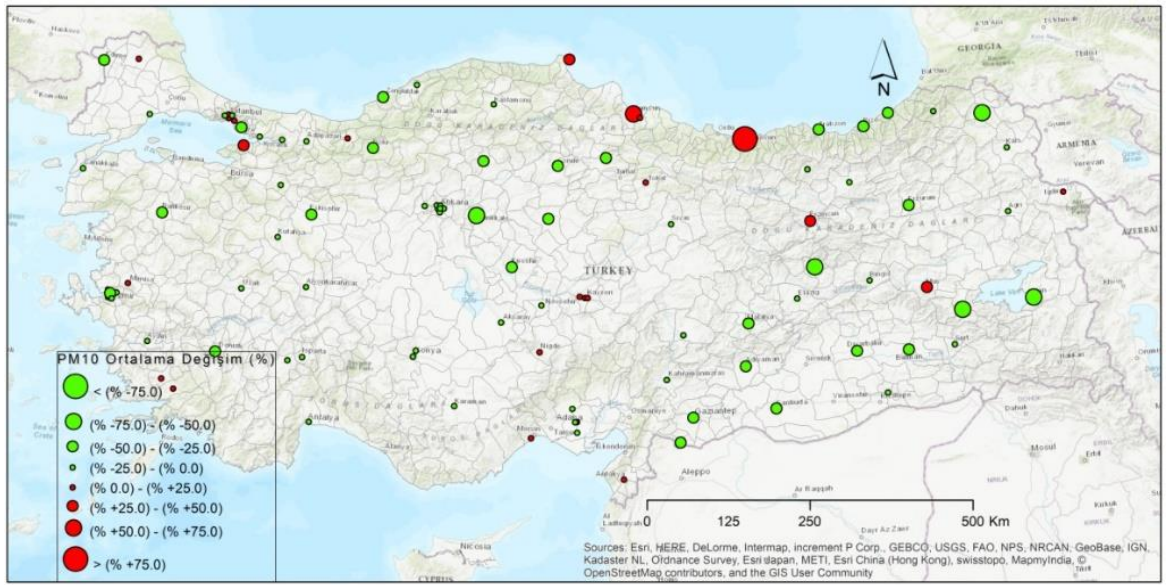

(c) 
Şekil 4. (a) 2009-2013 ve (b) 2014-2018 dönemleri $\mathrm{SO}_{2}$ değişken ortalamaları ve (c) dönemler arası $\mathrm{SO}_{2}$ ortalama değer değişimleri

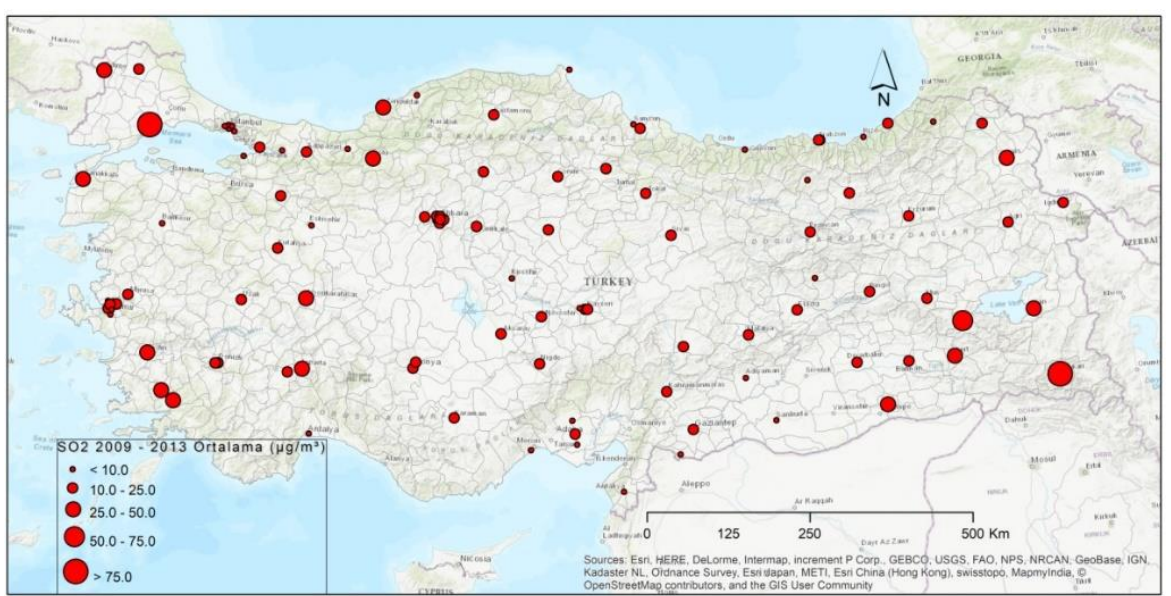

(a)

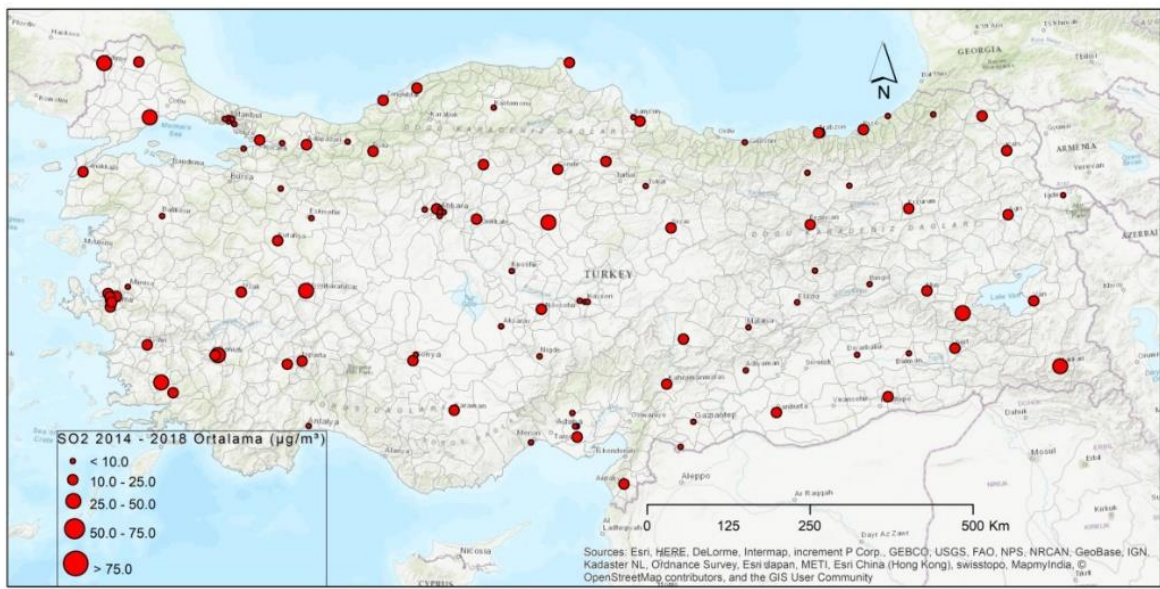

(b)

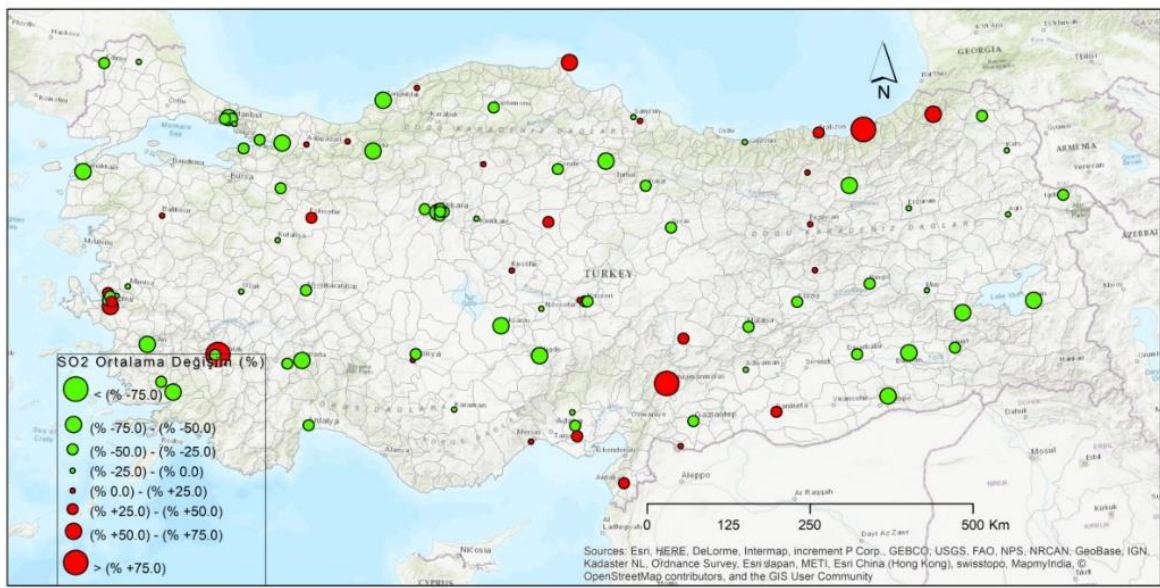

(c) 
$\mathrm{SO}_{2}$ değişkeni açısından ise, İstanbul Ümraniye, Osmaniye, Kahramanmaraş, Denizli-Bayramyeri ve Artvin istasyonlarında \% 70 üzeri ortalama değer artışlarının söz konusu olduğu, Kocaeli - OSB, Sinop, İzmir - Gaziemir ve Hatay Antakya istasyonlarında \% 50 ve üzeri artışların belirlendiği izlenmiştir. Türkiye genelinde kirletici değişken ortalamaları ve değişim yüzdeleri üzerinden gerçekleştirilen değerlendirmeler İstanbul, Ankara ve İzmir metropolleri özelinde detaylı olarak da incelenmiştir. Elde edilen bulgular, İstanbul ili açısından Aksaray, Alibeyköy ve Kadıköy ilçeleri için kaydedilen PM10 değerlerinde ikinci dönemdeki nisbi artışlara rağmen, incelenen geri kalan istasyonlarda ortalama kirletici değerlerinde azalmalar olduğuna işaret etmektedir (Şekil 5). İstanbul için $\mathrm{SO}_{2}$ değerlerinde ise çalışma kapsamındaki tüm il içi istasyonlarda ikinci dönemde azalan ortalamalar öne çıkmaktadır (Şekil 6).

Şekil 5: İstanbul İli istasyonlarına ait detay gösterimleri: (a) 2009-2013 dönemleri PM10 değişken ortalamaları, (b) dönemler arası PM10 ortalama değer değişimleri

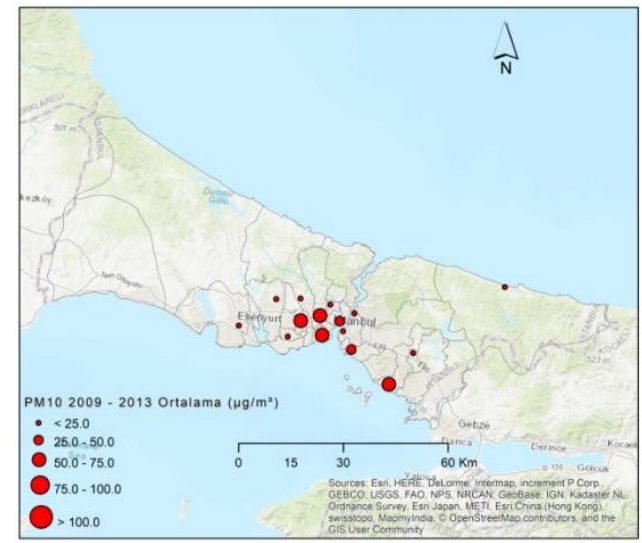

(a)

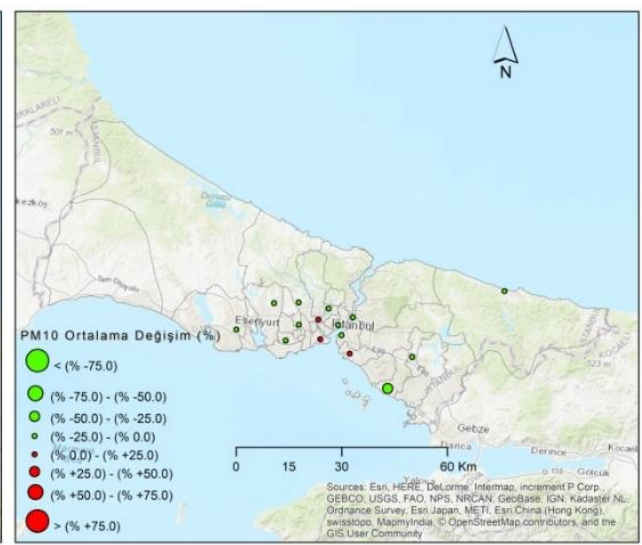

(b)

Şekil 6: İstanbul İli istasyonlarına ait detay gösterimleri: (a) 2009-2013 dönemleri $\mathrm{SO}_{2}$ değişken ortalamaları, (b) dönemler arası $\mathrm{SO}_{2}$ ortalama değer değişimleri

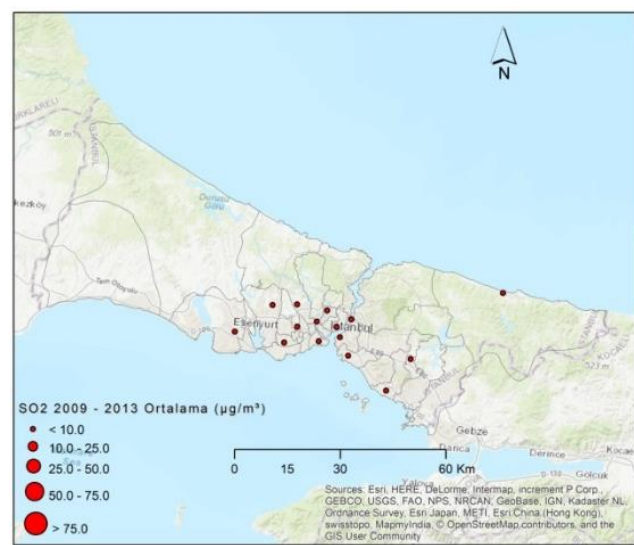

(a)

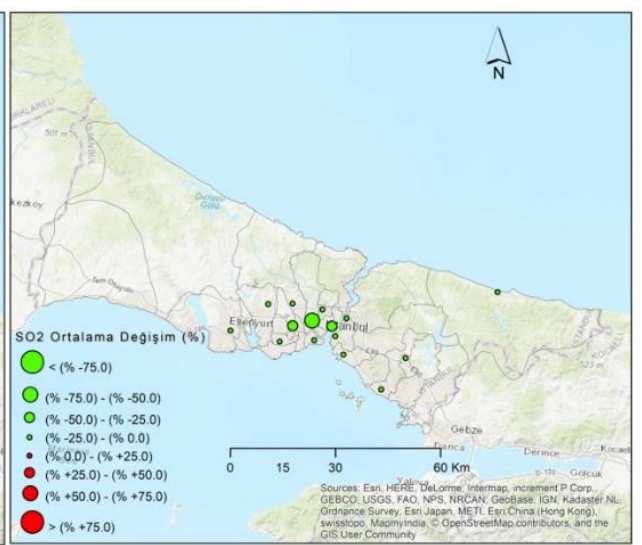

(b) 
Ankara için gerçekleştirilen detay incelemesinde, 2009-2013 döneminden 20142018 dönemine geçişte PM10 ortalama değerlerinde tüm incelenen istasyonlarda azalmalar tespit edilmiş olup (Şekil 7), azalma yönünde olmasına rağmen nispeten düşük yüzdeli bu değişimlere rağmen, $\mathrm{SO}_{2}$ değerlerinde Ankara istasyonlarının genelinde daha büyük oranda ortalama değer azalmaları izlenmiş, sadece Demetevler istasyonunda \% 14.8 oranında $\mathrm{SO}_{2}$ değerlerinde dönemsel artış olduğu kaydedilmiştir (Şekil 8).

Şekil 7: Ankara İli istasyonlarına ait detay gösterimleri: (a) 2009-2013 dönemleri PM10 değişken ortalamaları, (b) dönemler arası PM10 ortalama değer değişimleri

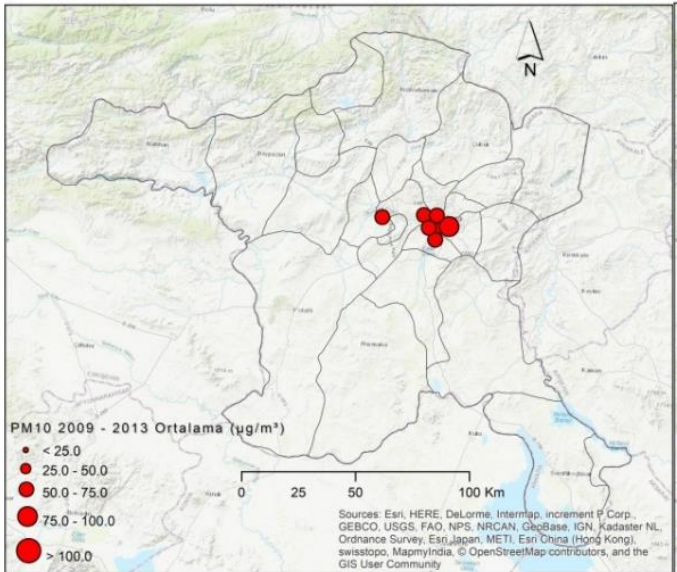

(a)

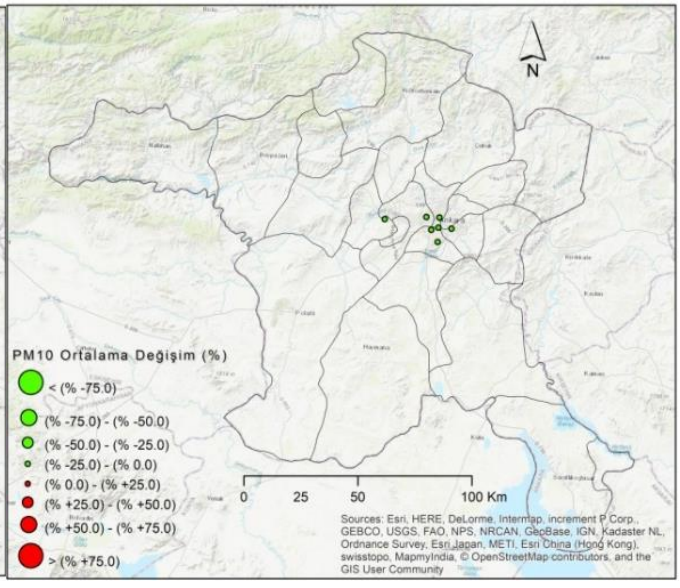

(b)

Şekil 8: Ankara İli istasyonlarına ait detay gösterimleri: (a) 2009-2013 dönemleri $\mathrm{SO}_{2}$ değişken ortalamaları, (b) dönemler arası $\mathrm{SO}_{2}$ ortalama değer değişimleri

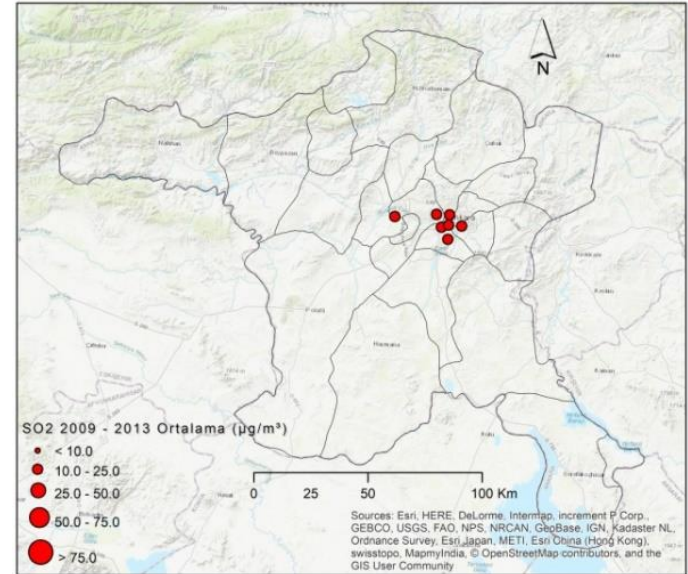

(a)

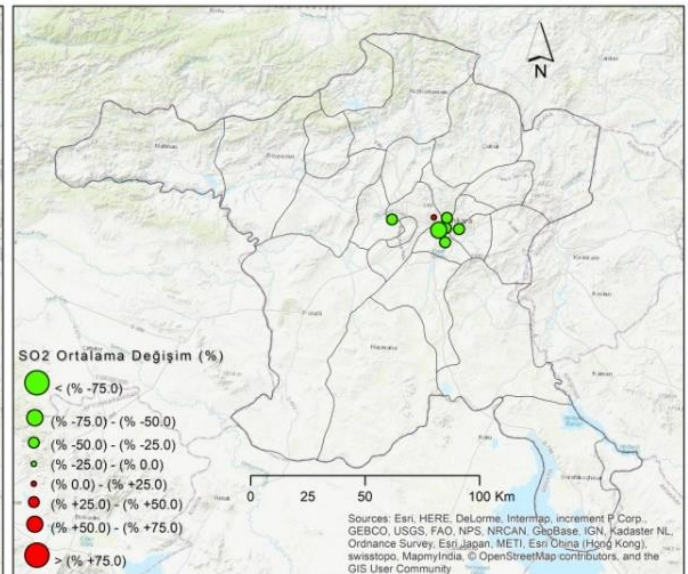

(b)

İzmir için gerçekleştirilen değerlendirmelerde ise yine PM10 dönemsel ortalama değerlerinde, ikinci dönemde ilk döneme kıyasla kapsam dahili tüm istasyonlarda azalmalar belirlenmiş olmakla birlikte (Şekil 9), $\mathrm{SO}_{2}$ değişimleri açısından yine ortalama değer azalmalarına işaret eden istasyonların yanı sıra, $6.87 \mu \mathrm{g} / \mathrm{m}^{3} \mathrm{den}$ 
$10.66 \mu \mathrm{g} / \mathrm{m}^{3} \mathrm{e}$ artış ile \% 55.3 oranında Gaziemir istasyonunda, $8.65 \mu \mathrm{g} / \mathrm{m}^{3} \mathrm{den}$ $12.37 \mu \mathrm{g} / \mathrm{m}^{31} \mathrm{e}$ artış ile \% 43.0 oranında Çiğli istasyonunda ve $8.25 \mu \mathrm{g} / \mathrm{m}^{31} \mathrm{den}$ $11.04 \mu \mathrm{g} / \mathrm{m}^{31} \mathrm{e}$ artış ile \% 33.9 oranında Şirinyer İBB istasyonunda dönemsel ortalama değer artışları belirlenmiştir (Şekil 10).

Şekil 9: İzmir İli istasyonlarına ait detay gösterimleri: (a) 2009-2013 dönemleri PM10 değişken ortalamaları, (b) dönemler arası PM10 ortalama değer değişimleri

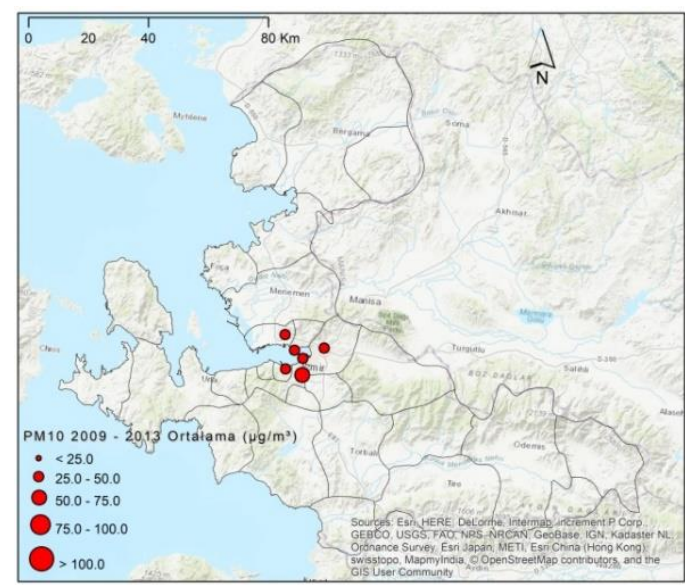

(a)

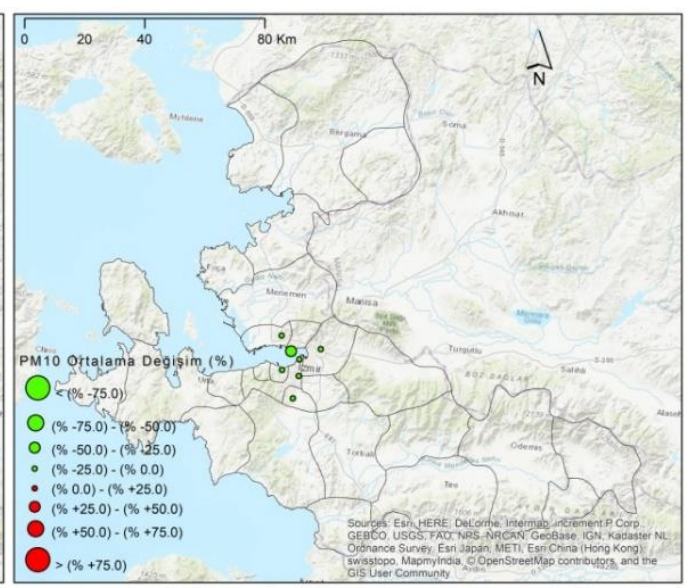

(b)

Şekil 10: İzmir İli istasyonlarına ait detay gösterimleri: (a) 2009-2013 dönemleri $\mathrm{SO}_{2}$ değişken ortalamaları, (b) dönemler arası $\mathrm{SO}_{2}$ ortalama değer değişimleri

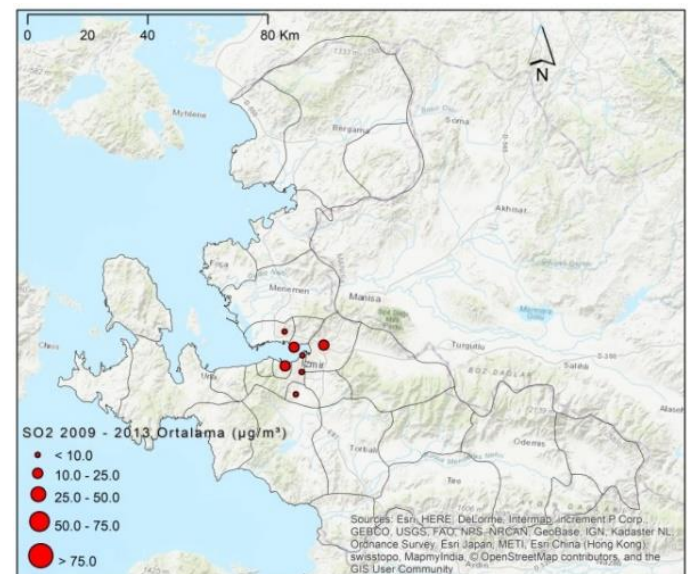

(a)

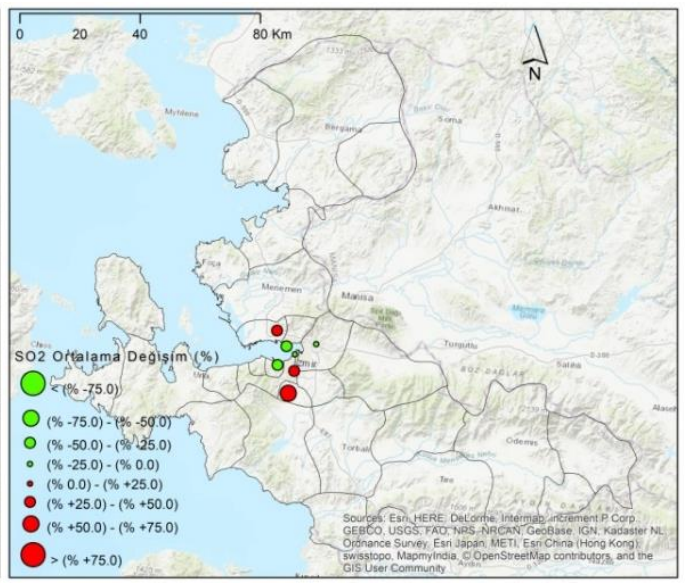

(b)

Dönemsel ortalamalar üzerinden gerçekleştirilen bu genel değerlendirmelerin yanı sıra, sunulan çalışmada dönemler içi eğilim analizleri de parametrik olmayan TheilSen eğilim derecelerinin RStudio ortamında hesaplanması üzerinden gerçekleştirilmiştir. Bu çalışma adımında özellikle, eğilim yönü değişimlerinin (artış eğiliminden azalma yönüne veya tersi yönde) ve eğilim derecesi (veya gelişim hızı) değişimlerinin ortaya koyulması amaçlanmıştır. İncelenen istasyonların bazılarında 2009-2013 ve 2014-2018 dönemlerinin her ikisinde de azalma veya 
artış yönünde eğilimler gözlenirken değişim derecesinde hızlanma (Şekil 11'deki Siirt istasyonu PM10 değerleri gibi) veya yavaşlamalar, bazı istasyonlarda ise azalma eğiliminden artış eğilimine geçiş (Şekil 12'deki Elazı̆̆ istasyonu PM10 değerleri örneğinde olduğu gibi) veya tam tersi yönde artıştan azalmaya geçiş şeklinde eğilim yönü değişimleri ortaya çıkarılmıştır.

Şekil 11: Siirt istasyonu PM10 gözlemleri örneğinde kirletici azalma eğiliminde dönemler arası karşılaştırma: (a) 2009-2013 dönemi ve (b) 2014-2018 dönemi

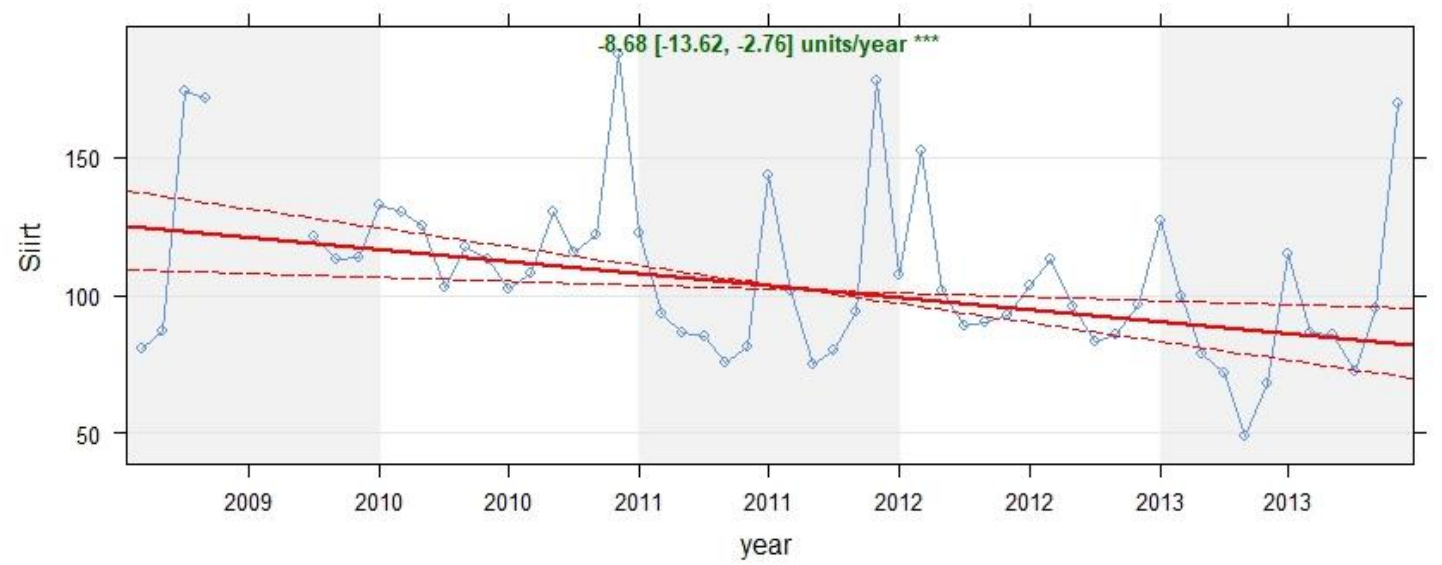

(a)

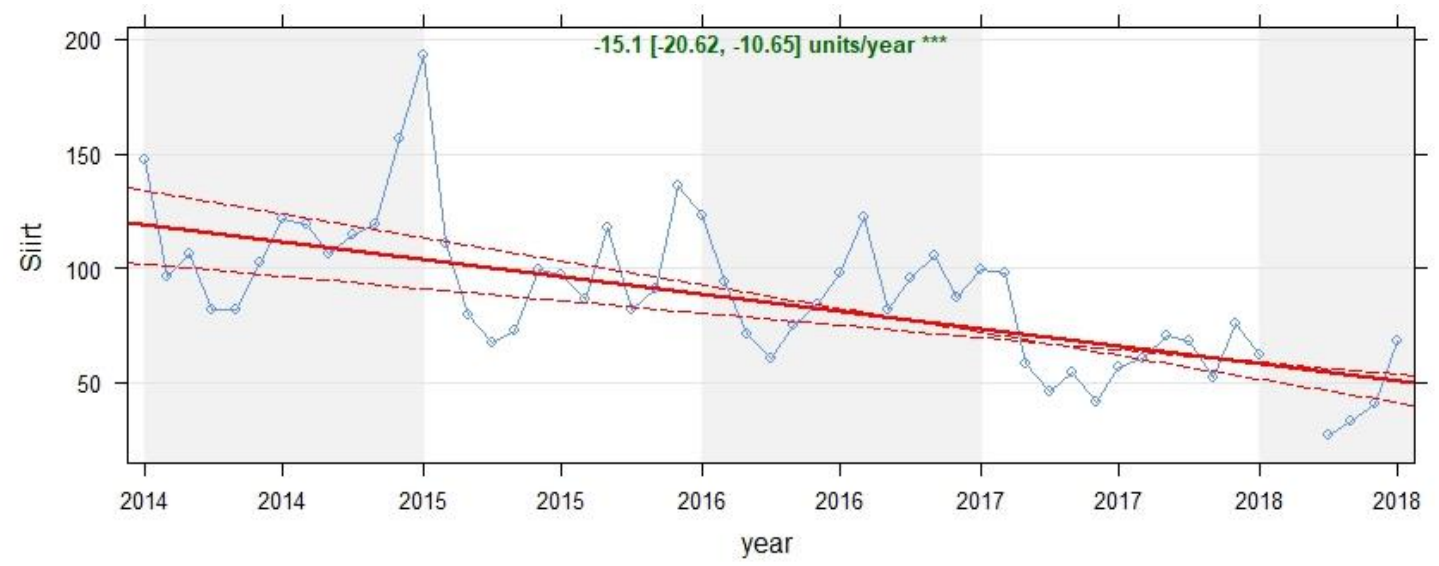

(b) 
Şekil 12: Elazı̆̆ istasyonu PM10 gözlemleri örneğinde kirletici eğilim yönü dönemler arası değişimi: (a) 2009-2013 dönemi azalma eğilimi ve (b) 2014-2018 dönemi artış eğilimi

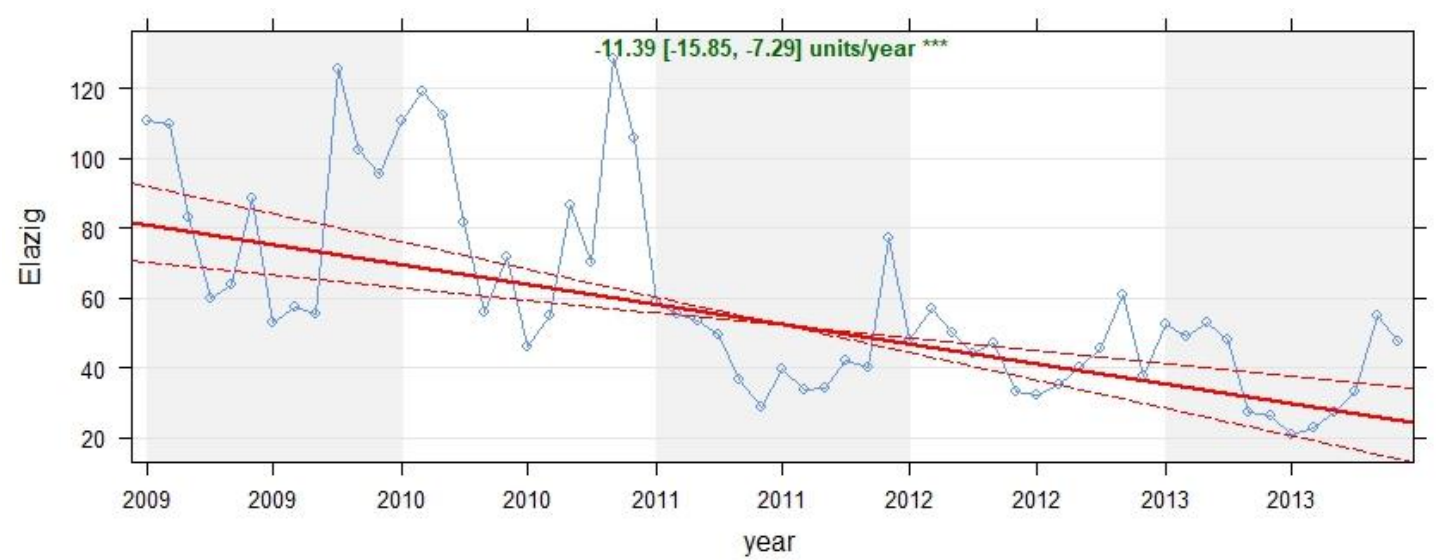

(a)

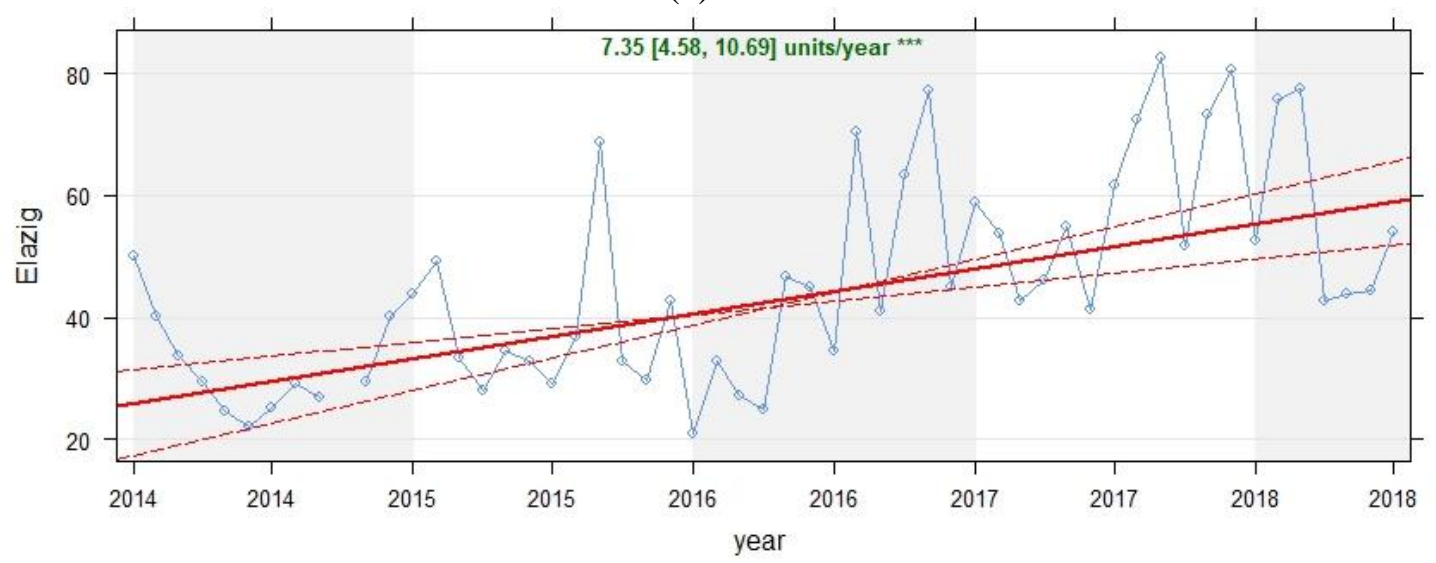

(b)

Türkiye genelinde çalışamaya dahil edilen tüm istasyonlar için PM10 değerlerinde 2009-2013 döneminde tespit edilen eğilimlerin varlığı Şekil 13a'da, 2014-2018 dönemi yine aynı değişken eğilim belirlemeleri Şekil 13b'de, iki dönem arasındaki eğilim değişimleri de Şekil 13c'de sunulmaktadır. Eğilim değişimlerinde özellikle, durağan gidiş veya azalma eğiliminden artış yönüne geçiş ve ayrıca artış eğilimi hızındaki yükselme türünden değişimlerin öne çıkarılması amaçlanmıştır.

Değişken değerleri aylık zaman serileri üzerinde istatistiksel eğilim varlığının belirlenmesine yönelik benzer çalışmalar istasyonlarda kaydedilen $\mathrm{SO}_{2}$ değişken değerleri için de tekrar edilerek sonuçlar Şekil 14'deki dağılım haritaları üzerinde sunulmuştur. 
Şekil 13: (a) 2009-2013 ve (b) 2014-2018 dönemleri PM10 değişken eğilimleri ve (c) dönemler arası eğilim değişimleri

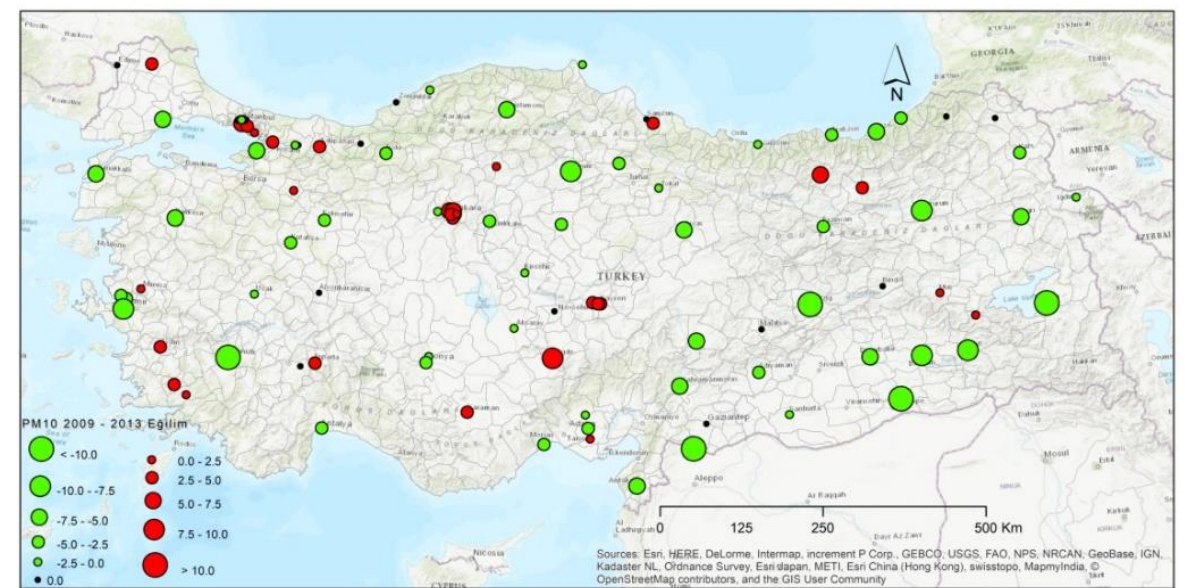

(a)

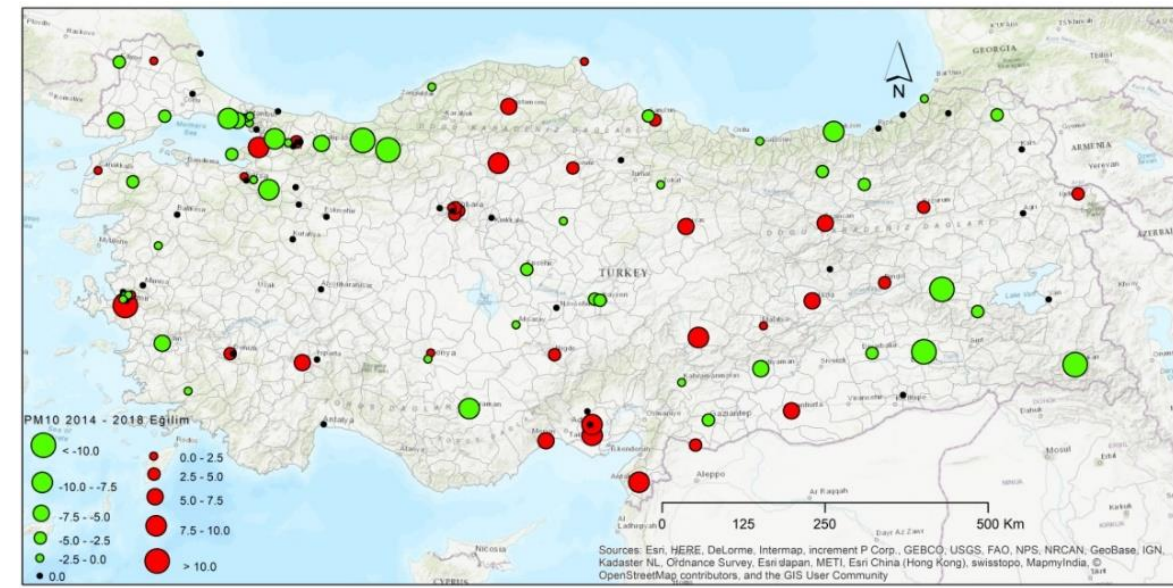

(b)

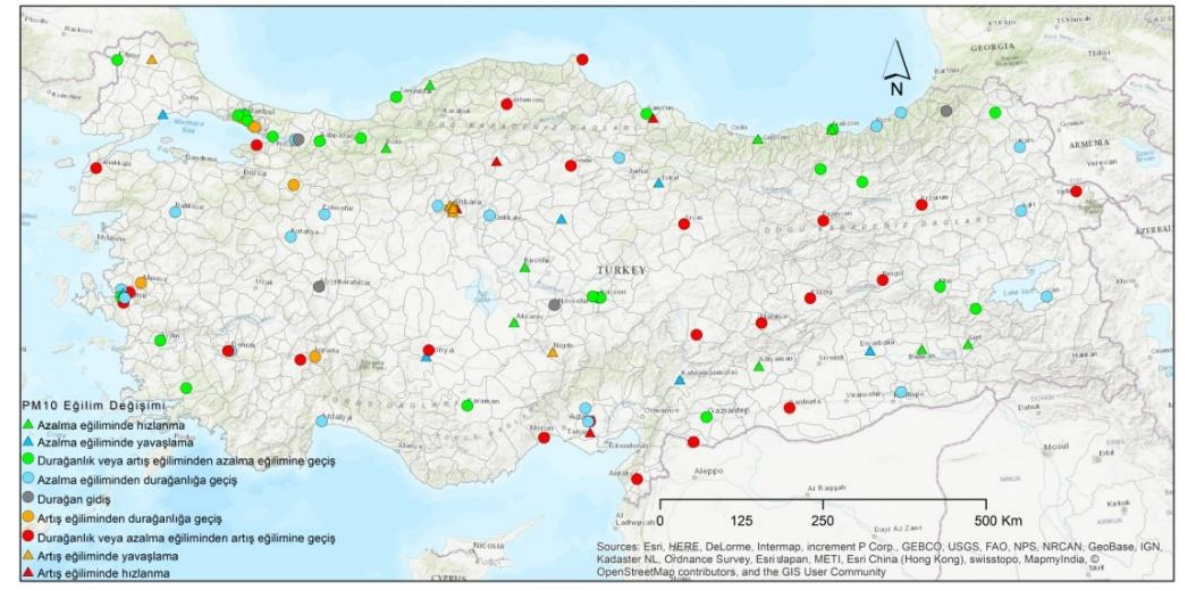

(c) 
Şekil 14: (a) 2009-2013 ve (b) 2014-2018 dönemleri $\mathrm{SO}_{2}$ değişken eğilimleri ve (c) dönemler arası eğilim değişimleri

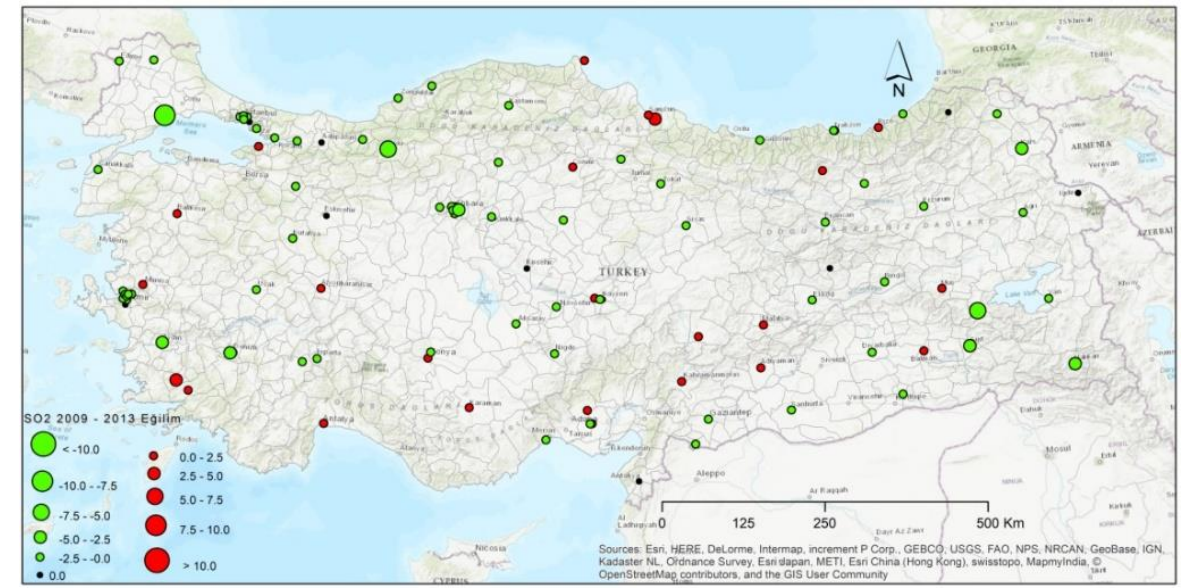

(a)

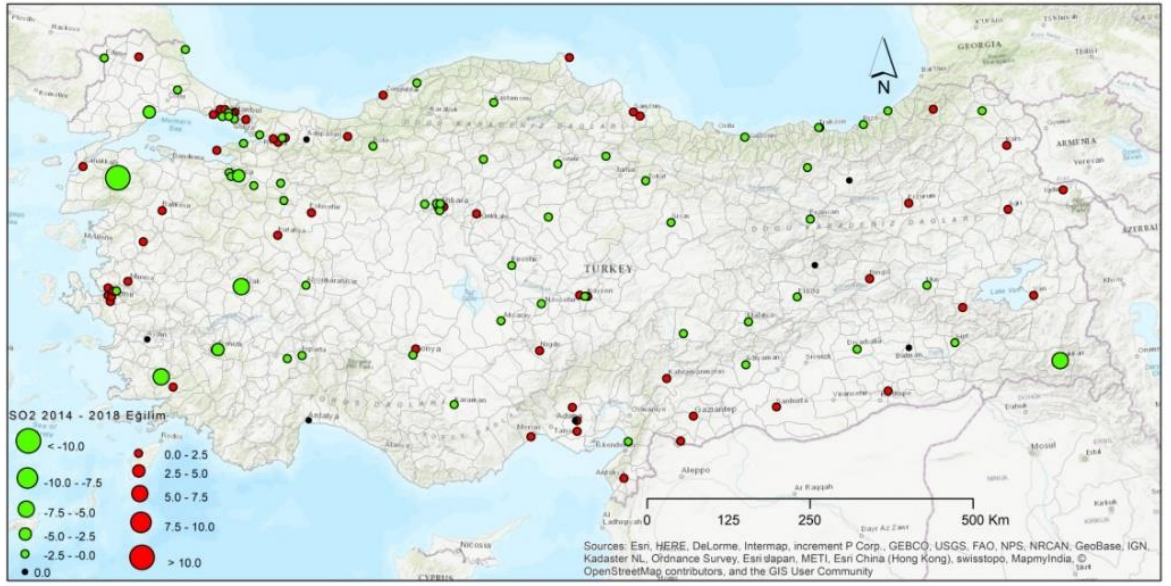

(b)

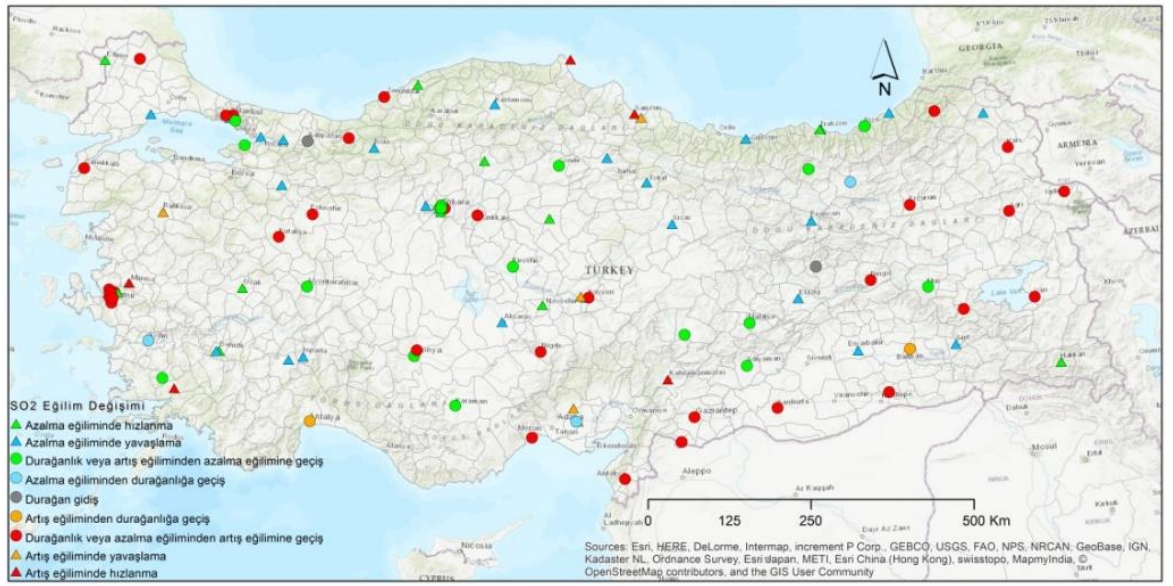

(c) 
RStudio yazılımı araç seti kapsamında TheilSen fonksiyon kodu kullanılarak gerçekleştirilen bu eğilim varlığı tespit çalışmalarında, hesaplanan eğilim derecelerine ait olarak sonuçların güven olasılıkları ve istatistiksel anlamlılık dereceleri de ayrıca kaydedilerek istasyon konumlarıyla ilişkilendirilmiş ve bu güven olasılıkları yine harita üzerinde Şekil 15 'de ortaya koyulmuştur. İstasyonlara ait $\mathrm{PM} 10$ ve $\mathrm{SO}_{2}$ dönemsel eğilim derecelerinin bu kestirimlere ait anlamlılık dereceleriyle birlikte incelenmesi ve daha kesin yargılarla ifade edilebilecek eğilim varlıklarının daha düşük olasılıkla ortaya koyulabilecek eğilim varlıklarında farklı şekilde değerlendirilmesi gereği önem taşımaktadır.

Şekil 15: İstasyonlarda gözlenmiş (a) 2009-2013 dönemi ve (b) 2014-2018 dönemi PM10, (c) 2009-2013 dönemi ve (b) 2014-2018 dönemi $\mathrm{SO}_{2}$ değişken değerlerine ait eğilim tespitleri ve dereceleri için \%90, 95, 99 ve 99.9 güven düzeylerinin mekansal gösterimleri

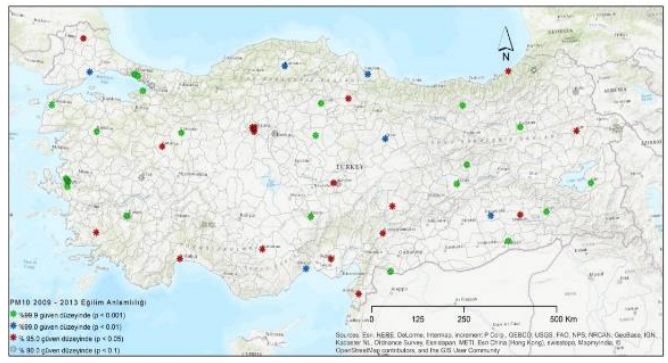

(a)

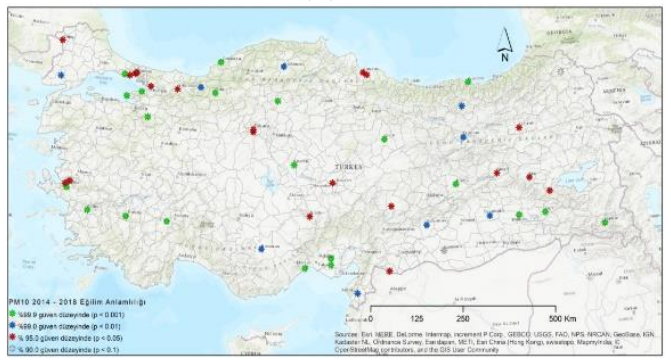

(c)

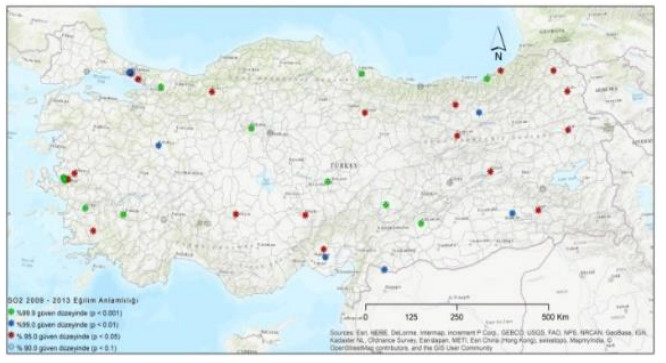

(b)

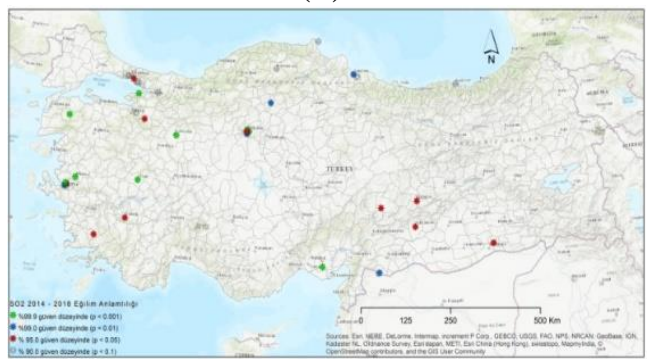

(d)

İncelenen dönemler arası eğilim yönü/derecesi değişimleri, değişken ortalamaları belirlemelerindeki yaklaşıma benzer şekilde İstanbul, Ankara ve İzmir örnekleri üzerinde de uygulanmıştır. İstanbul özelinde, her iki dönemde de eğilim varlığı tespit edilen istasyonlar arası eğilim değişimleri her iki değişken açısından incelendiğinde, farklı karakteristik değişimlerin yanında özellikle $\mathrm{SO}_{2}$ açısından Esenler istasyonunda, \% 90 istatistiksel güven ifadesiyle, azalma yönünden artış eğilimine geçiş şeklinde kayda değer bir durum öne çıkmaktadır (Şekil 16). 
Şekil 16: İstanbul İli istasyonlarına ait detay gösterimleri: dönemler arası (a) PM10 ve (b) $\mathrm{SO}_{2}$ değişkenlerine ilişkin eğilim değişimleri

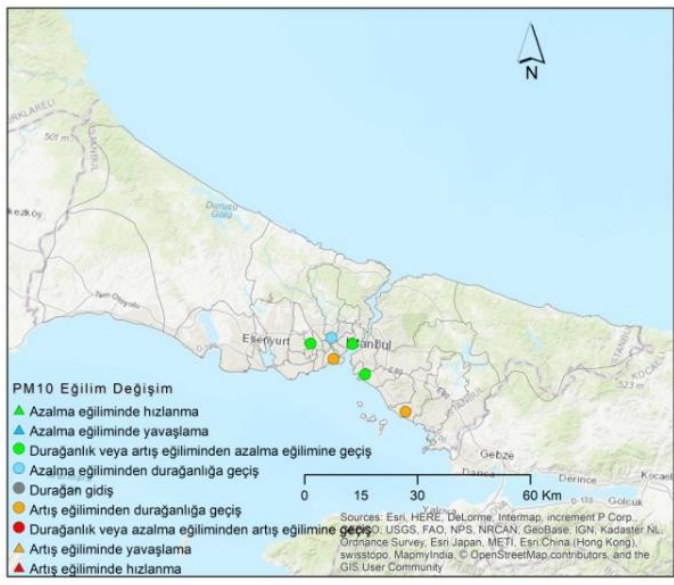

(a)

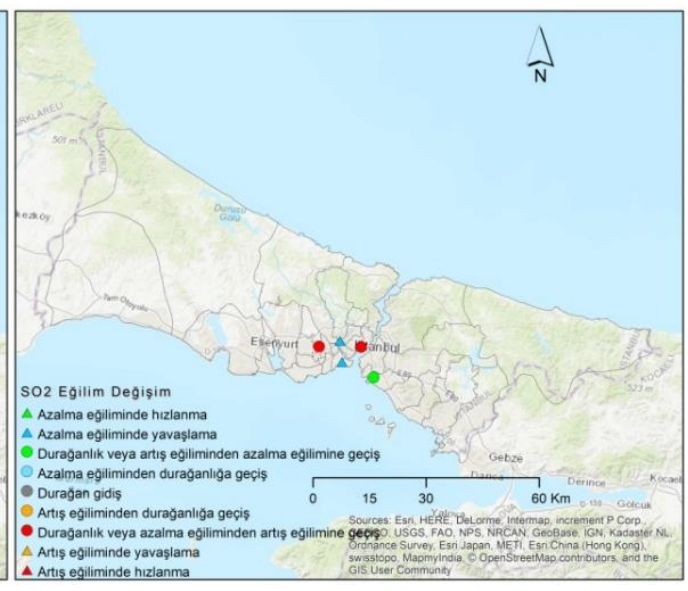

(b)

Ankara için benzer sonuçlar Şekil 17'de, İzmir İli için ise Şekil 18'de sunulmakta olup, İzmir istasyonlarında özellikle de $\mathrm{SO}_{2}$ değişkeni açısından ilk dönemdeki genelde olumlu görünümden 2014-2018 döneminde artış eğilimine geçiş durumu daha detaylı inceleme gereği açısından dikkate değer olmaktadır.

Şekil 17: Ankara İli istasyonlarına ait detay gösterimleri: dönemler arası (a) $\mathrm{PM} 10$ ve (b) $\mathrm{SO}_{2}$ değişkenlerine ilişskin eğilim değişimleri

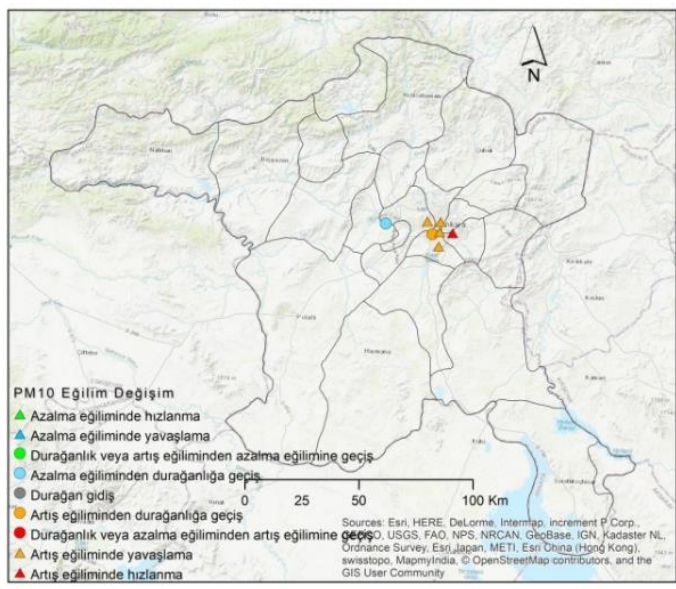

(a)

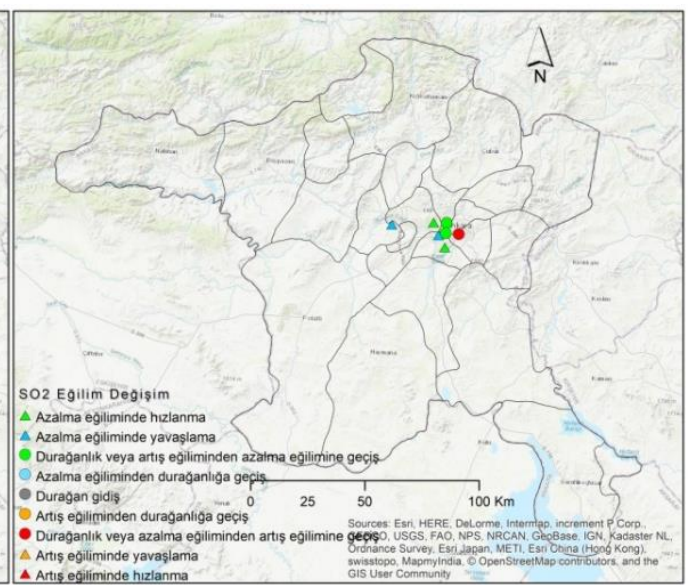

(b)

Genel ifadeyle, sunulan çalışmada Türkiye genelinde incelemeye dahil edilebilen istasyonlarda iki kirletici değişken üzerinden gerçekleştirilen tüm çalışmaların, olası hassas durumların ortaya çıkarılması amacına hizmet etmesi ve genel gösterge niteliği taşıması amaçlanmış olup, herhangi bir olumsuzluğa işaret eden bulgulara ait istasyon konumlarında, olumsuzluğa yol açan durumların tespiti, sürücü etmenlerin araştırılması, verilerin kalite ve güvenilirlik açısından kontrolü ile sonuçların doğrulanmasına yönelik istatistiksel açıdan farklı yöntemler ve 
yaklaşımlar üzerinden de analizlerin yinelenmesi yönünde araştırma çalışmalarının planlanması ve geliştirilmesi büyük önem taşımaktadır.

Şekil 18: İzmir İli istasyonlarına ait detay gösterimleri: dönemler arası (a) PM10 ve (b) $\mathrm{SO}_{2}$ değişkenlerine ilişkin eğilim değişimleri

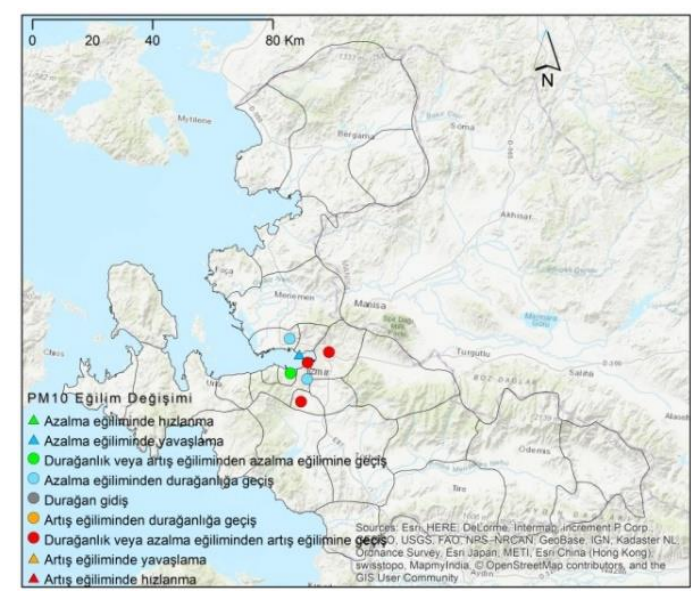

(a)

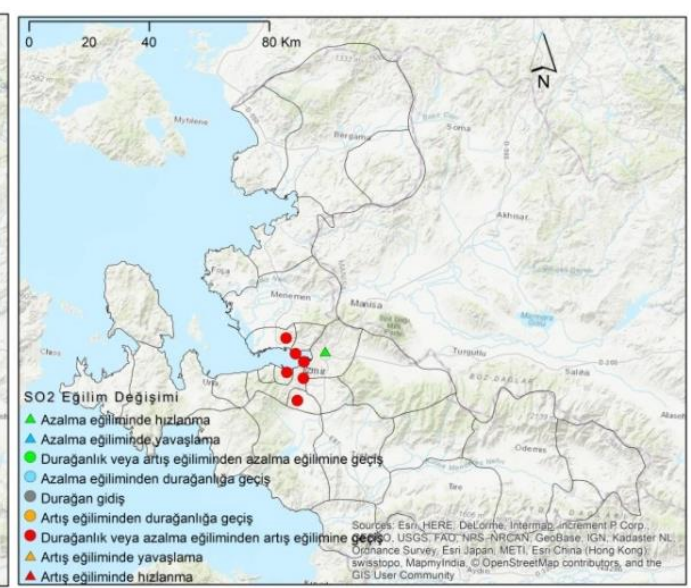

(b)

\section{Kaynakça}

Akyürek, Ö., Arslan, O. ve Karademir, A. (2013). SO 2 ve PM10 Hava Kirliliği Parametrelerinin CBS ile Konumsal Analizi: Kocaeli Örneği. TMMOB Coğrafi Bilgi Sistemleri Kongresi, Ankara.

ÇŞB, Çevre ve Şehircilik Bakanlığı. (2019a). Hava Kalitesi İndeksi. Çevre ve Şehircilik Bakanlığı, Marmara Temiz Hava Merkezi Müdürlüğü, http://mthm.havaizleme.gov.tr/secure/HAVA\%20KAL\%DDTES\%DD\%20\%

DDNDEKS\%DD.htm (Erişim: 15.02.2019).

ÇŞB, Çevre ve Şehircilik Bakanlığı. (2019b). Ulusal Hava Kalitesi İzleme Ağı, Haritalar-Tüm İstasyonlar. http://index.havaizleme.gov.tr/Map (Erişim: 17.02.2019).

ÇŞB, Çevre ve Şehircilik Bakanlığı. (2019c). Sürekli İzleme Merkezi (SİM). Çevre ve Şehircilik Bakanlığı, https://www.havaizleme.gov.tr/Services/AirQuality (Erişim: 15.02.2019).

İskender, S., Bolu, F., Y1lmaz, M. ve Mayda, A.S. (2016). Düzce Hava Kalitesi İzleme İstasyonu 1 Ekim 2011 - 31 Mart 2015 Tarihleri Arasındaki Verilerinin İncelenmesi. Düzce Üniversitesi Sağllk Bilimleri Enstitüsü Dergisi, 6(3), 161167.

Mayda, A.S. ve Y1lmaz, M. (2013) Düzce Hava Kalitesi İzleme İstasyonu 20072011 Yılları Arası Verilerinin Değerlendirilmesi. TAF Preventive Medicine Bulletin, 12(1), 11-18. 
Oğuz, K. ve Pekin, M.A. (2015) Meteorolojik Koşulların Hava Kirliliği Üzerine Etkilerinin İncelenmesi: Keçiören İlçesi Örneği. VII. Uluslararası Katılımlı Atmosfer Bilimleri Sempozyumu, İstanbul.

Resmî Gazete (2008) Hava Kalitesi Değerlendirme ve Yönetimi Yönetmeliği. Tarih: 06.06.2008, Say1: 26898.

Şişman, E. (2019) Türkiye'de Seçilen Hava Kalitesi İzleme İstasyonları için Eğilim (Trend) Değerlendirmeleri. Doğal Afetler ve Çevre Dergisi, 5(1), 134-152.

Theil, H. (1950) A rank-invariant method of linear and polynomial regression analysis. I, II, III. Nederl. Akad. Wetensch., Proc., 53: 386-392, 521-525, $1397-$ 1412. 